\title{
Reforma Zakonu Księży Marianów 1909 roku jako przykład "bezkonfliktowej" reformy
}

Każda reforma ma swoich zwolenników i przeciwników, dlatego oczywiste jest, że każda zmiana może być przyczyną konfliktów między tymi grupami osób. Widać to szczególnie wyraźnie, gdy dokonują się poważne zmiany jakiejś struktury.

Celem niniejszego artykułu jest spojrzenie na jedną ze zmian, jakie dokonały się w historii Zgromadzenia Księży Marianów Niepokalanego Poczęcia NMP. Na szczególną uwagę zasługuje fakt, iż reforma marianów w 1909 roku przeszła właściwie bez konfliktu.

W pierwszej części zostanie przedstawiony rys historyczny Zakonu oraz kontekst reformy. W drugiej części na podstawie opublikowanych dokumentów dotyczących odnowienia zgromadzenia marianów ${ }^{1}$ zaprezentowany zostanie przebieg reformy. Natomiast w trzeciej części krótko przedstawiona "spóźniona" reakcja na reformę ze strony osób podających się za prawdziwych marianów.

W zakończeniu podjęto próbę odpowiedzi na pytanie, dlaczego reforma marianów przebiegła w sposób bezkonfliktowy.

1 Odrodzenie Zgromadzenia Księży Marianów w latach 19og-1910, dokumenty, red. J. Bukowicz, T. Górski, tłum. H. Szymanel, Warszawa 1995. Jest to zbór dokumentów z Archiwum Kongregacji Instytutów Życia Konsekrowanego i Stowarzyszeń Życia Apostolskiego, Archiwum Generalnego Zgromadzenia Księży Marianów Niepokalanego Poczęcia NMP (Rzym) oraz Litewskiego Centralnego Archiwum Państwowego (Wilno). Zawiera on kościelne dokumenty oficjalne oraz korespondencję między osobami zaangażowanymi w reformę zgromadzenia marianów. 


\section{Zakon marianów oraz kontekst historyczny reformy}

Zakon marianów został założony w Polsce przez Stanisława Papczyńskiego w 1670 roku, kiedy to, wystąpiwszy z zakonu pijarów, złożył Oblatioº, czyli oddanie się, w którym ofiarując siebie Bogu i Maryi, równocześnie wyraził zamiar założenia nowego zgromadzenia zakonnego, poświęconego czci Niepokalanego Poczęcia Najświętszej Maryi Panny.

Zgromadzenie rozwijało się, choć nie bez trudności: w 1699 roku uzyskano aprobatę papieską oraz zezwolono marianom składać tzw. śluby uroczyste. W chwili śmierci założyciela zakon liczył około dwudziestu zakonników i posiadał trzy klasztory33. Natomiast w XVIII wieku zakon miał już placówki nie tylko w Polsce, ale też za granicą - w Portugalii oraz w Rzymie, zaś zakonników było ponad $140^{4}$.

Jednak wskutek rozbiorów Polski liczba zakonników i placówek zaczęła się zmniejszać. Marianie byli zmuszeni dostosować się do zaistniałej sytuacji, gdy władze świeckie rozpoczęły politykę nastawioną wrogo wobec zakonów. Domy zakonne objęto kasatą, zakonnicy opuszczali swoje klasztory, a władze zakonne napotykały przeszkody w wykonywaniu swych dotychczasowych funkcji ${ }^{5}$.

W Królestwie Polskim pierwsza kasata zakonów została zrealizowana w 1819 roku. Władze umotywowały ją złym stanem finansowym Kościoła, dlatego podjęto decyzję o likwidacji części klasztorów, by przekazać fundusze i wyposażenie innym instytucjom kościelnym. Należy zaznaczyć, że ta pierwsza kasata dotyczyła około 30 domów zakonnych, jednak żaden klasztor mariański na skutek tych działań nie został zniesiony ${ }^{6}$.

Mocnym ciosem dla marianów był ukaz kasacyjny z 1864 roku, który wydano jako swoistą zemstę władzy wobec Kościoła po powstaniu

S. Papczyński, Ofiarowanie siebie. Oblatio, w: S. Papczyński. Pisma zebrane, red. A. Pakuła, tłum. K. Krzyżanowski, B. Kupis, W. Makoś, R.R. Piętka, R. Sawa, A. Stefańczyk, Warszawa 2007, s. 1422-1423.

3 Por. K. Krzyżanowski, Powstanie i rozwój zakonu za życia założyciela, w: Marianie 1673-1973, red. J. Bukowicz, T. Górski, Rzym 1975, s. 17-39.

4 B. Jakimowicz, Stabilizacja i rozwój zakonu w XVIII wieku, w: Marianie 1673-1973, op. cit., s. 48.

5 Por. P. Gach, Zakon marianów w XIX wieku, w: Marianie 1673-1973, op. cit., s. $70-73$.

6 Por. D. Olszewski, Kontekst historyczno-religijny odnowienia Zakonu Marianów (XIX/XX w.), w: Za Chrystusa i Kościół. Materiały z sympozjum historyczno-teologicznego z okazji 10o. rocznicy odnowienia i reformy Zgromadzenia Księży Marianów (19og-20og), Licheń Stary, 24-28 maja 2009 r., red. J. Kumala, Licheń Stary 2010, s. $18-19$. 
styczniowym. Zostały zniesione wszystkie placówki zakonne, w których liczba zakonników wynosiła mniej niż osiem osób. Ponadto zabroniono zakonom przyjmowanie nowych kandydatów, doprowadzając je w ten sposób do wymarcia ${ }^{7}$.

Marianie w tym czasie nie uniknęli skutków kasat - domy zakonne w Polsce i za granicą zostały zlikwidowane, z około 70 ówczesnych marianów połowa znalazła się w trzech klasztorach, 11 zakonników zesłano na Sybir, 9 kleryków i nowicjuszy opuściło zakon, dwóch kapłanów wyemigrowało, natomiast reszta osiadła w różnych parafiach ${ }^{8}$.

W latach 1865-1866 zostały zlikwidowane dwa na trzy klasztory w Mirosławiu i w Igłówce. Pozostał tylko klasztor w Mariampolu, jednak warunki w nim panujące nie sprzyjały rozwojowi życia zakonnego, dlatego zakonnicy starali się u biskupa i u władz państwowych o przyjęcie ich do diecezji i opuszczenie klasztoru. I tak, w 1867 roku w Mariampolskim klasztorze mieszkało 24 marianów, w 1897 już tylko trzech, a w 1908 roku pozostał jeden zakonnik, a był nim o. Wincenty Sękowski ${ }^{9}$ (Senkus), który od roku 1892 pełnił funkcję przełożonego generalnego zakonu. W związku z tym, że liczba zakonników w klasztorze zmalała, sam klasztor w Mariampolu został zlikwidowany, a pozostałe posiadłości zgromadzenia przeszły na rzecz parafii w 1904 roku $^{10}$. Sam o. W. Sękowski został w niej na prawach rezydenta, parafia zaś była zarządzana przez innego kapłana.

Należy jednak wskazać na pewien ważny nurt w organizacji życia zakonnego, który pojawił się wskutek wspomnianych wyżej działań władz państwowych. Chodzi tu mianowicie o utworzenie ukrytych form życia zakonnego. Powstawanie zgromadzeń ukrytych wiąże się przede wszystkim z działalnością o. Honorata Koźmińskiego, dzięki któremu powstało 26 zgromadzeń zakonnych, w większości żeńskich, które działając w ukryciu, prowadziły różne formy apostolatu oraz działalności społeczne $^{11}$. Idea ukrytych zgromadzeń zakonnych prawdopodobnie wpłynęła

7 D. Olszewski, Kontekst historyczno-religijny..., op. cit., s. 18-19.

8 P. Gach, Zakon marianów..., op. cit., s. 92.

9 Wincenty Sękowski (Senkus) (1840-1911) - urodził się w parafii Szumsk we wsi Aszmoniszki na Litwie. Uczył się w gimnazjum w Mariampolu. Do zakonu marianów wstąpił w 1858 roku. W latach 1862-1866 studiował w Akademii Duchownej w Warszawie. Na kapłana wyświęcony został w 1864 roku. Przełożony generalny zakonu marianów od 1892 roku. Pełnił ten urząd do śmierci w 1911 roku.

10 P. Gach, Zakon marianów..., op. cit., s. 93.

11 D. Olszewski, Kontekst..., op. cit., s. 20-21. 
także na odnowiciela zakonu marianów - bł. Jerzego Matulewicza ${ }^{12}$ (Matulaitis), który dobrze znał o. Koźmińskiego oraz ściśle współpracował z założonym przezeń Zgromadzeniem Sióstr Najświętszego Imienia Jezus.

Znawcy historii marianów wskazują jeszcze na jeden czynnik, który ich zdaniem miał wpływ na poglądy odnowiciela oraz na dokonaną reformę zgromadzenia. Była to mianowicie świadomość pewnej izolacji Kościoła od świata na skutek rozwoju nauk oraz progresu technicznego. Odpowiedzią na ten stan rzeczy stała się działalność papieża Leona XIII, który zachęcał ludzi Kościoła do studiowania nauk przyrodniczych, filozofii, historii. Ks. Jerzy Matulewicz podczas studiów we Fryburgu został uformowany właśnie w tym duchu aktywności społecznej oraz pogłębionej znajomości nauk „świeckich"13. Możliwe, że to jedna z przyczyn, dla której później do odnowionego zgromadzenia zgłaszało się tak wielu chętnych, szukających "Czegoś więcej".

Można więc stwierdzić, że z jednej strony zakon marianów z powodów obiektywnych chylił się ku upadkowi, jednak te same okoliczności wpłynęły na reformę w zgromadzeniu, której przeprowadzenie uważane jest za jeden z przykładów bezkonfliktowej przemiany.

\section{Reforma zakonu marianów w świetle dokumentów}

Ramy czasowe reformy zakonu wytyczają dostępne dokumenty powiązane z reformą. Począwszy od listu ks. Jerzego Matulewicza do generała zakonu o. Wincentego Sękowskiego z 8 września 1908 roku, a skończywszy na

Jerzy Matulewicz (Matulaitis) (1871-1927) - urodził się we wsi Lugino, w parafii mariampolskiej. Został ochrzczony przez ówczesnego generała marianów o. J. Czesnasa, natomiast o. W. Sękowski (Senkus) był jego nauczycielem religii w gimnazjum. Wstąpił do Seminarium Duchownego w Kielcach, a następnie studiował w Warszawie, w Petersburgu oraz we Fryburgu. Został wyświęcony na kapłana w Petersburgu w 1898 roku. Ściśle współpracował z o. H. Koźmińskim, założycielem wielu potajemnych zgromadzeń zakonnych. Wiele pracował społecznie, był m.in. współzałożycielem Stowarzyszenia Robotników Chrześcijańskich. W 1907 roku został profesorem Cesarskiej Rzymskokatolickiej Akademii Duchownej w Petersburgu. W 1909 roku wstąpił potajemnie do Zgromadzenia Księży Marianów, które następnie odnowił. Pełnił urząd przełożonego generalnego aż do śmierci. W latach 1918-1925 był biskupem wileńskim. Po rezygnacji z tego urzędu został mianowany wizytatorem apostolskim na Litwie i podniesiony do godności arcybiskupa. Zmarł 27 stycznia 1927 roku. Zaliczony w poczet błogosławionych 28 czerwca 1987 roku.

13 Por. S. Matulis, T. Górski, Odnowienie marianów, w: Marianie 1673-1973, op. cit., s. $98-99$. 
zatwierdzeniu zreformowanego już zgromadzenia marianów przez Stolicę Apostolską 28 listopada 1910 roku. Wszystkie dokumenty przetłumaczono na język polski i opublikowano w 1995 roku w ramach cyklu Fontes Historiae Marianorum przez Wydawnictwo Księży Marianów.

Kluczową postacią reformy marianów był ks. Jerzy Matulewicz, który razem z Franciszkiem Buczysem ${ }^{14}$ podjął decyzję o wstąpieniu do zakonu marianów. W liście do generała zakonu - o. W. Sękowskiego ks. Matulewicz wyraził nadzieję, że władze udzielą pozwolenia jemu i jeszcze trzem jego towarzyszom na wstąpienie do zakonu, by mogli „przywdziać habit mariański"15. Faktycznie, po 1905 roku, przez wzgląd na dekret cara Mikołaja II (1894-1917) pojawiła się nadzieja na wznowienie działalności zakonu. Księża J. Matulewicz i F. Buczys podejmowali starania, by przywrócić klasztor mariampolski zakonowi marianów, jednak te działania były bezskuteczne. Wydaje się, że pierwotną ideą Matulewicza i Buczysa było odnowić zgromadzenie bez reformy ${ }^{16}$. Rzeczywiście, z treści listu można wnioskować, że początkowym zamiarem było właśnie odrodzenie zakonu poczynając od przywrócenia marianom prawa własności do klasztoru w Mariampolu. Natomiast bez odpowiedzi pozostaje pytanie, na ile radykalnie w tym czasie ks. Matulewicz był gotów reformować marianów. Dalsza korespondencja między ks. Matulewiczem i o. Sękowskim wydaje się potwierdzać daną tezę: ks. Jerzy pisał o zamiarach przeprowadzenia rozmów z dostojnikami kościelnymi oraz przedstawicielami władz państwowych, informował

14 Franciszek Buczys (Bučys) (1872-1951) - urodził się w Szyłgale na Litwie. Uczył się w gimnazjum w Mariampolu, następnie studiował w seminarium duchownym w Sejnach, w Akademii Duchownej w Petersburgu oraz na uniwersytecie we Fryburgu. Święcenia kapłańskie przyjął w 1899 roku. Pracował jako wykładowca w Cesarskiej Rzymskokatolickiej Akademii Duchownej w Petersburgu. W roku 1909 potajemnie przyjęty do nowicjatu w zakonie marianów, gdzie w 1910 roku złożył śluby zakonne. W latach 1915-1920 przebywał w USA, gdzie organizował struktury zakonne zgromadzenia marianów. W 1927 roku wybrany na generała marianów na 6 lat, zaś w 1930 na prośbę papieża przeszedł na obrządek wschodni i został mianowany ordynariuszem katolików obrządku bizantyjsko-słowiańskiego i przyjął sakrę biskupa. Jednak tego urzędu nie mógł sprawować z powodu sytuacji politycznej. Od roku 1939 do śmierci sprawował urząd przełożonego generalnego zgromadzenia marianów.

15 Prośba ks. Jerzego Matulewicza do generała Wincentego Sękowskiego o przyjęcie do zakonu jego wraz z przyjaciółmi. Petersburg, 8-9 września 19o8, w: Odrodzenie..., op. cit., s. $51-52$.

16 Por. S. Matulis, Marianie za błogosławionego Jerzego Matulaitisa-Matulewicza, Warszawa-Lublin 2008, s. 113. 
jednocześnie o już dokonanych działaniach ${ }^{17}$. Dopiero w późniejszej korespondencji pojawiła się idea reformy.

Należy zaznaczyć, że o. Sękowski, zgodziwszy się na działania o. Matulewicza, wyraźnie wskazał, że akceptuje jego poczynania:

W razie mojej śmierci przekazuję wszystkie przywileje i prawa na Czcigodnego Profesora, z których dziś zwłaszcza można skorzystać i u Stolicy Apostolskiej wyjednać zatwierdzenie i uznanie. W moim biurku są dokumenty z Rzymu dane, i potwierdzające to Zgromadzenie ${ }^{18}$.

Jednak późniejsze listy o. Sękowskiego, który działając zgodnie ze wskazaniami Matulewicza, podjął konieczne działania w sprawie przywrócenia prawa własności na klasztor, wskazują na rosnący niepokój i pewną rozpacz z powodu bezskuteczności wysiłków - ani władze państwowe, ani dostojnicy kościelni nie odpowiedzieli bowiem na jego prośby ${ }^{19}$.

Ks. Matulewicz kontynuował działania odrodzenia zakonu marianów. Uzyskawszy listy polecające, postarał się o paszport, by udać się do Rzymu dla załatwienia spraw odnowienia marianów. Najciekawsza dla rozumienia podjętego tematu jest prośba o. Sękowskiego skierowana do Stolicy Apostolskiej. Prośbę swą motywował tym, że jest ostatnim żyjącym marianinem, będącym przełożonym generalnym zakonu. Prosił o to, by Stolica Apostolska „w jakiś nadzwyczajny sposób" zaradziła niebezpieczeństwu likwidacji zakonu. Zwrócił się z propozycją dopuszczenia ks. Matulewicza do złożenia profesji zakonnej bez obowiązku nowicjatu oraz o zwolnienie z oznak zewnętrznych przynależności do zakonu ${ }^{20}$.

Por. List ks. J. Matulewicza do o. W. Sękowskiego o staraniach w celu przywrócenia klasztoru w Mariampolu. Petersburg, $3^{1}$ października 19o8, w: Odrodzenie..., op. cit., s. $57-58$.

18 List o. W. Sękowskiego do ks. J. Matulewicza wyrażający radość z powodu zgłaszających się kandydatów do zakonu. Mariampol, 14 października 19o8, w: Odrodzenie..., op. cit., s. 56 .

19 Por. List o. W. Sękowskiego do ks. J. Matulewicza o trudnościach przywrócenia klasztoru w Mariampolu. Mariampol, 6 listopada 19o8; List o. W. Sękowskiego do ks. J. Matulewicza o staraniach w Warszawie w celu wznowienia klasztoru mariampolskiego. Mariampol, 11 grudnia 1go8; List o. W. Sękowskiego do ks. J. Matulewicza z zapytaniem, czy jest nadzieja na wznowienie klasztoru. Mariampol, 24 kwietnia 19og, w: Odrodzenie..., op. cit., s. 59-62.

20

Prośba generała W. Sękowskiego do Piusa X o zabezpieczenie istnienia marianów w sposób nadzwyczajny oraz upoważnienie ks. J. Matulewicza do załatwiania spraw związanych z dalszym istnieniem zakonu. Mariampol, 20 lipca 19og, w: Odrodzenie..., op. cit., s. $67-69$. 
List ten potwierdza tezę, że sam o. Sękowski odczuwał konieczność przekształcenia zakonu marianów. Gdyby nie dokonane zmiany marianie przestaliby istnieć. Chociaż F. Buczys zaznaczył, że początkowo o. Sękowski nie chciał zgodzić się na rezygnację z habitu zakonnego przez marianów. Jednakże później zmienił zdanie ${ }^{21}$.

W liście do F. Buczysa z lipca 1909 roku J. Matulewicz podzielił się planem przeprowadzenia reformy w zakonie marianów. Wyraźnie da się zauważyć w tym miejscu plan działań ${ }^{22}$, które jako przedstawiciel generała zakonu marianów przedstawił Stolicy Apostolskiej, prosząc by zgromadzenie zakonne mogło funkcjonować w ukryciu, w niczym nie zdradzając swego istnienia wobec władz państwowych. Zmiany, o które prosił, brzmiały następująco:

1. Dyspensa od stroju zakonnego.

2. Zmiana ślubów uroczystych na śluby proste.

3. Dostosowanie redagowanych Konstytucji zgromadzenia do norm wydanych przez kongregację zakonników w 1901 roku.

4. Pozwolenie mu na złożenie profesji zakonnej bez konieczności nowicjatu.

5. Pozwolenie na przyjęcie potajemnie do nowicjatu ks. F. Buczysa.

6. Pozwolenie na przyjęcie potajemnie na okres próby innych kandydatów.

7. Prośba o zachowanie w tajemnicy odnowienia Zgromadzenia Marianów wobec władz.

Odpowiedź prefekta kongregacji zakonników była pozytywna i upoważniała biskupa sejneńskiego do przyjęcia w szeregi marianów księży Matulewicza i Buczysa, pod warunkiem, że po trzech miesiącach przedstawią listy polecające ordynariuszy mohylewskiego, warszawskiego i sejneńskiego. Dokument ten został podpisany przez podsekretarza kongregacji na polecenie prefekta ${ }^{23}$. Potwierdzeniem zgody ze strony generała marianów o. W. Sękowskiego tej reformy stanowi protokół przyjęcia księży Matulewicza i Buczysa do zgromadzenia marianów 29 sierpnia 1909 roku, na którym o. Sękowski złożył swój podpis. Ten protokół w całości wygląda następująco:

21 S. Matulis, Marianie 1673-1973, op. cit., s. 114.

22 Por. List ks. J. Matulewicza do ks. Fr. Buczysa o motywach udania się do Rzymu. Warszawa 23 lipca 19og, w: Odrodzenie..., op. cit., s. 69-71.

23 Wstępny reskrypt Kongregacji Zakonników dotyczacy odnowienia Zgromadzenia Księży Marianów. Rzym, 2 sierpnia 19og, w: Odrodzenie..., op. cit., s. 77-78. 
Warszawa, 29 sierpnia 1909

Ja, Kazimierz Ruszkiewicz, biskup beryseński i sufragan warszawski, niniejszym stwierdzam, że - na mocy władzy udzielonej mi przez Świętą Kongregację Zakonników, pismem Nr 3544/o9 - dnia 29 sierpnia 1909 r., włączyłem do Zgromadzenia Księży Marianów, wobec Przełożonego Generalnego tegoż Zgromadzenia Wincentego Sękowskiego, petentów Jerzego Matulewicza i Franciszka Buczysa, doktorów teologii i profesorów Akademii Duchownej w Petersburgu: Jerzego Matulewicza dopuściłem do złożenia pierwszych ślubów rocznych, a Franciszka Buczysa do rozpoczęcia nowicjatu.

Akt ten zostaje potwierdzony podpisami Przewielebnego Przełożonego Generalnego i petentów.

Przełożony Generalny: ks. Wincenty Sękowski

Petenci: ks. Jerzy Matulewicz

ks. Franciszek Buczys

Wiarygodność powyższego podpisuję i polecam opatrzyć pieczęcią.

+Kazimierz Ruszkiewicz

Wikariusz Generalny Archidiecezji Warszawskiej24

Należy dodać, że generałem odnawianego zgromadzenia nadal pozostawał o. Sękowski, dlatego ks. Matulewicz zdał mu sprawozdanie ze swojej działalności oraz poprosił o dokumenty potrzebne do załatwienia bieżących spraw ${ }^{25}$, natomiast o. Sękowski wyraził aprobatę dla działalności marianów oraz przekazał wiadomości o swoich poczynaniach wobec władz kościelnych. Działalność o. Sękowskiego dotyczyła uregulowania spraw zgromadzenia ${ }^{26}$. Jest to kolejny dowód na zgodę o. Sękowskiego na dokonanie tak radykalnej reformy zgromadzenia.

Ponadto w tym czasie ks. J. Matulewicz zebrał wymagane listy polecające od hierarchów Kościoła i przesłał je do kongregacji zakonników. Kontynuował również pracę nad nowym projektem konstytucji Zgromadzenia

Protokół przyjęcia do Zgromadzenia Księży Marianów ks. J. Matulewicza i ks. Fr. Buczysa przez wikariusza generalnego archidiecezji warszawskiej bpa Kazimierza Ruszkiewicza. Warszawa, 29 sierpnia 19og, w: Odrodzenie..., op. cit.., s. 86-87. Por. Sprawozdanie ks. J. Matulewicza z życia wspólnoty mariańskiej w Petersburgu dla generała W. Sękowskiego. Petersburg, 3 października 19og, w: Odrodzenie..., op. cit., s. 87-90. ka 19og, w: Odrodzenie..., op. cit., s. 92-93. 
Księży Marianów. Przygotowane projekty konstytucji wraz z wymaganymi załącznikami zostały przesłane do Kongregacji zakonników, opatrzone prośbą o. Sękowskiego, który podkreśla po raz kolejny, że wszystkie zmiany dzieją się za jego zgodą i z jego polecenia ${ }^{27}$.

Ostatnim dokumentem, na podstawie którego można stwierdzić, że reforma zgromadzenia marianów rzeczywiście została dokonana, jest dekret kompetentnej władzy kościelnej - Kongregacji Zakonników, w którym wyraźnie stwierdzono, że ów zakon został założony w XVII wieku i zatwierdzony przez papieży Innocentego XII i Innocentego XIII, oraz że udzielono marianom zezwolenia na składanie ślubów uroczystych. W XIX wieku rozwój zakonu został zahamowany do tego stopnia, że w końcu pozostał tylko jeden zakonnik, będący przełożonym generalnym. Jednak dzięki wysiłkom kapłanów zgromadzenie zostało odnowione i zreformowane zgodnie z przepisami Kongregacji Zakonników. Papież Pius X zatwierdził Zgromadzenie Księży Marianów Niepokalanego Poczęcia NMP z drobnymi zmianami w Konstytucji ${ }^{28}$.

Podsumowując, należy dodać, że wszystkie zmiany dokonały się jeszcze za życia o. Wincentego Sękowskiego przy jego czynnym udziale w tej reformie. Początkowo przeciwny wobec zniesienia obowiązku noszenia stroju zakonnego w końcu wyraził zgodę na wszystkie zmiany wprowadzane przez ks. Jerzego Matulewicza. Obecne Zgromadzenie Księży Marianów jest tym samym Zgromadzeniem, założonym przez S. Papczyńskiego, chociaż zreformowane. Jest ono spadkobiercą dziedzictwa duchowego i tożsamości zakonu marianów wbrew opiniom przeciwnym.

3. Problem tzw. stanisławitów, czyli opóźniony opór wobec odnowy Wartą uwagi w kontekście omawianego tematu jest sprawa tzw. stanisławitów - stowarzyszenia, które powstało w 1928 roku z ramienia biskupa podlaskiego Henryka Przeździeckiego (1875-1939) z siedzibą w Janowie Podlaskim. Istniało do definitywnego rozwiązania go przez biskupa Ignacego Świrskiego (1885-1968) 1 września 1955 roku $^{29}$.

27 Prośba generała W. Sękowskiego do Piusa X o zatwierdzenie nowych konstytucji. Mariampol, 7 sierpnia 1910, w: Odrodzenie..., op. cit., s. 106-107.

28 Dekret Kongregacji Zakonników zatwierdzający zreformowane Zgromadzenie Księży Marianów i nowe konstytucje. Rzym, 28 listopada 1910, w: Odrodzenie..., op. cit., S. $108-109$.

29 J. Marecki, Stowarzyszenie stanisławitów (1928-1955), „Folia Historica Cracoviensia", t. 9 (2003), s. 105-106. 
Geneza wspólnoty "stanisławitów" sięga czasów wspomnianej już polityki władzy państwowej, wrogo nastawionej do życia zakonnego. Część członków zakonu marianów rozproszyła się po parafiach, jednak uzasadnioną wydaje się teza, że przynajmniej niektórzy z nich starali się nie utracić własnej tożsamości mariańskiej.

Według informacji podanych przez osoby związane ze stowarzyszeniem stanisławitów w 1898 roku w Górze Kalwarii marianie, którzy żyli w pojedynkę, zebrali się na kapitule, gdzie dokonali wyboru przełożonego zakonu - o. Bernarda Pielasińskiego (1832-1914). Nie ma jednak żadnych dokumentów kompetentnej władzy kościelnej poświadczających to wydarzenie oprócz sprzecznych ze sobą świadectw stanisławity Józefa Pietrzaka (1882-1954). Możliwe, że z braku kontaktów z klasztorem w Mariampolu nie wiedzieli oni o dokonanym wyborze o. Sękowskiego na generała ${ }^{30}$. W związku z tym powstaje pytanie o ważność działań marianów w rozproszeniu. Kanonista ks. prof. Julian Kałowski, przeprowadziwszy analizę prawną, stwierdził, że nawet jeżeli faktycznie nastąpił wybór o. Pielasińskiego na generała marianów, był on nieważny, dlatego wszyscy, którzy złożyli śluby zakonne nie na ręce o. Sękowskiego, nie mogą nazywać się marianami ${ }^{31}$.

O. Sękowski uważał siebie za ostatniego żyjącego marianina, chociaż rzeczywiście mogli jeszcze w innych miejscach żyć marianie, którzy opuścili klasztor za czasów prześladowań. Jednak nie można jednoznacznie stwierdzić, czy o. Sękowski wiedział o istnieniu i działalności o. Pielasińskiego oraz jego następców, którzy uważali się za „właściwych" marianów.

Po zaprzestaniu wrogich działań władzy świeckiej wobec zakonów biskup Henryk Przeździecki pragnął odnowić życie zakonne na terenie powierzonej mu diecezji, dlatego kiedy w 1927 roku na teren diecezji przybyli „biali marianie", skierował do Stolicy Apostolskiej zapytanie o zakon marianów, czy można składać śluby zakonne według dawnych Konstytucji Zakonu ${ }^{32}$. Odpowiedź Stolicy Apostolskiej była następująca: zreformowane

30 J. Marecki, Stowarzyszenie stanisławitów (1928-1955), op. cit., s. 108-109.

31 Por. J. Kałowski, Ocena zarzutów przeciwko legalności odnowy Zakonu Marianów, „Prawo Kanoniczne. Kwartalnik prawno-historyczny" t. 21, nr 3-4 (1978), s. $71-95$.

32 Pismo bpa podlaskiego Henryka Przeździeckiego do Kongregacji Zakonników, dotyczace ewentualnego przekazania mariańskiego klasztoru w Goźlinie Józefowi Pietrzakowi i jego towarzyszom. Siedlce, 10 grudnia 1927, w: Odrodzenie..., op. cit., s. $120-121$. 
zgromadzenie marianów jest właśnie tym samym zakonem marianów, który został przekształcony, jednak ta zmiana nie jest utworzeniem nowego zgromadzenia zakonnego, ale prawną kontynuacją dawnego zakonu. Jeżeli osoby, które zgłosiły się do biskupa, pragną utworzyć nowe zgromadzenie, to należy postąpić zgodnie z prawem, jak przy utworzeniu nowych zgromadzeń zakonnych. Zasugerowano również, by zgłaszający się mężczyźni nawiązali kontakt ze Zgromadzeniem Księży Marianów33.

W związku z tą odpowiedzią biskup Przeździecki zdecydował o założeniu Stowarzyszenia Diecezjalnego Czcicieli Niepokalanie Poczętej Dziewicy - Królowej Pokoju, wspomożycieli dusz czyśćcowych, czyli stanisławitów ${ }^{34}$.

W ciągu 27 lat istnienia stowarzyszenie liczyło około 50 członków kapłanów, kleryków i braci. Z biegiem czasu wyznaczony przez biskupa komisarz do spraw stowarzyszenia zgłaszał o istnieniu problemów, sugerował zmianę przełożonego. Ponadto, staraniem wspomnianego wyżej Józefa Pietrzaka, jednego z członków stowarzyszenia, w prasie ukazały się artykuły przedstawiające stanisławitów jako prawdziwych marianów. Kilkakrotnie zarząd zgromadzenia marianów musiał interweniować w tej sprawie ${ }^{35}$.

Następca biskupa Przeździeckiego, biskup Ignacy Świrski, nie był przychylny stowarzyszeniu, nie zgodził się on na podniesienie rangi wspólnoty stanisławitów do zgromadzenia. Zgodnie z zaleceniem Konferencji Episkopatu dane stowarzyszenie zostało ostatecznie rozwiązane, klerycy stowarzyszenia mogli kontynuować naukę w wybranym przez siebie seminarium duchownym, a kapłani zostali włączeni w szeregi duchowieństwa diecezjalnego ${ }^{36}$.

Koniecznym jest, w ramach niniejszego artykułu, ukazanie, że po rozwiązaniu stowarzyszenia stanisławitów, nadal istnieli autorzy, którzy utrzymywali, że nie było żadnej reformy zakonu marianów, a właściwymi marianami byli właśnie stanisławici. Prace te wydano w polemicznym i oskarżycielskim tonie. Mogą oni stanowić przykład „opóźnionej" reakcji na reformę zgromadzenia marianów, czyli opóźnionego konfliktu, którego

Reskrypt Kongregacji Zakonników do bpa podlaskiego H. Przeździeckiego wyjaśniajacy reformę Zgromadzenia Księży Marianów z roku 1910. Rzym, 25 kwietnia 1928, w: Odrodzenie..., op. cit., s. 122-124. J. Marecki, Stowarzyszenie stanisławitów..., op. cit., s. 111-112. Por. J. Marecki, Stowarzyszenie stanisławitów..., op. cit., s. 116-117. Por. J. Marecki, Stowarzyszenie stanisławitów..., op. cit., s. 122-123. 
źródłem była jednak nie sama reforma, ale inne motywy, o które należy pytać wspomnianych autorów ${ }^{37}$. Konflikt ten jednak został już definitywnie zażegnany ${ }^{38}$.

\section{Zakończenie}

Podsumowując, należy podjąć próbę odpowiedzi na pytanie, jakie czynniki wpłynęły na to, że reforma Zgromadzenia Księży Marianów dokonała się właściwie bez konfliktów, choć boleśnie ją odczuto.

Przede wszystkim na skutek działań władzy świeckiej, gdy przy życiu został właściwie jedyny członek zakonu, nie było już grupy osób, która sprzeciwiałaby się reformie. Jednakże o. Sękowski, mimo że był schorowany, nie mógł być uważany za biernego obserwatora działań reformatorskich ks. Matulewicza. Jako generał zakonu sam przecież brał czynny udział we wszystkich działaniach ks. Matulewicza. Jak już wspomniano wyżej, miał on swoje zdanie nt. reformy, dlatego przez pewien czas sprzeciwiał się zmianie stroju zakonnego marianów na sutannę.

Wynika z tego również drugi powód - rozumienie konieczności zmian. Mimo że na początku przewodnią ideą księży Matulewicza i Buczysa była restauracja klasztoru w Mariampolu i przywdzianie białego habitu, później wszyscy zainteresowani stwierdzili, że nie ma innej możliwości przetrwania zakonu, jak tylko jego radykalna reforma.

Trzecią przyczyną braku konfliktu była współpraca „starego" i „nowego". O. Sękowski, jak i ks. Matulewicz podczas reformy działali razem, nie czyniąc przeszkód sobie nawzajem oraz darząc się szacunkiem, czego potwierdzeniem jest ich korespondencja.

Kolejny ważny moment stanowiła obecność władzy wyższej, do której obaj się odnoszą i której byli podporządkowani. Wszystkie reformatorskie poczynania przedstawiano Stolicy Apostolskiej, mianowicie Kongregacji

Publikacje autorów, zaprzeczających dokonanej reformie: M. Kołodziejski, Zakon oo. Marianów a Zgromadzenie ks. ks. Marianów (Kontrowersyjne problemy t. zw. odnowy), Rzym-Toruń 1980; J. Muniak, O. Bernard od Krzyża Pielasiński marianin biały (1832-1914), Kraków-Częstochowa 1963; tenże, Mons. Jerzy Matulewicz i jego dzieło w świetle faktów, Rzym - Kraków 1980.

38 Problemem odnowy Zgromadzenia Marianów zajmował się ks. prof. Julian Kałowski MIC, który wykazał od strony kanonicznej legalność odnowy Zgromadzenia Marianów w świetle roszczeń stanisławitów: J. Kałowski, Ocena zarzutów..., op. cit., s. 71-95; Por. tenże, Kontrowersyjne problemy odnowy Zakonu Marianów, "Summarum. Sprawozdania Towarzystwa Naukowego KUL", 2(22) 1973, s. $118-127$. 
ds. Zakonników, która była kompetentnym organem w kwestii reformy. Dla obu było oczywistym, że jeżeli kompetentna władza kościelna godzi się na reformę, to nie ma powodów do konfliktu z powodu rezygnacji z dotychczasowej formy istnienia zakonu.

Na końcu można stwierdzić, że wymienione przyczyny braku konfliktów, choćby częściowo, mogą posłużyć jako pewien paradygmat działania dla wszystkich, którzy w przyszłości chcieliby przeprowadzić różnego rodzaju strukturalne reformy, by dokonały się one bez większych konfliktów między zainteresowanymi stronami. 


\section{Bibliografia}

Źródła

Dekret Kongregacji Zakonników zatwierdzajacy zreformowane Zgromadzenie Księży Marianów i nowe konstytucje. Rzym, 28 listopada 1910, w: Odrodzenie Zgromadzenia Księży Marianów w latach 19og-1910, dokumenty, red. J. Bukowicz, T. Górski, tłum. H. Szymanel, Warszawa 1995, s. 108-109.

List generała W. Sękowskiego do ks. J. Matulewicza. Mariampol, 26 października 19og, w: Odrodzenie Zgromadzenia Księży Marianów w latach 19og-1910, dokumenty, red. J. Bukowicz, T. Górski, tłum. H. Szymanel, Warszawa 1995, s. 92-93.

List ks. J. Matulewicza do ks. Fr. Buczysa o motywach udania się do Rzymu. Warszawa 23 lipca 19og, w: Odrodzenie Zgromadzenia Księży Marianów w latach 19og-1910, dokumenty, red. J. Bukowicz, T. Górski, tłum. H. Szymanel, Warszawa 1995, s. 69-71.

List ks. J. Matulewicza do o. W. Sękowskiego o staraniach w celu przywrócenia klasztoru w Mariampolu. Petersburg, 31 października 19o8, w: Odrodzenie Zgromadzenia Księży Marianów w latach 19og1910, dokumenty, red. J. Bukowicz, T. Górski, tłum. H. Szymanel, Warszawa 1995, s. 57-58.

List o. W. Sękowskiego do ks. J. Matulewicza o staraniach w Warszawie w celu wznowienia klasztoru mariampolskiego. Mariampol, 11 grudnia 19o8, w: Odrodzenie Zgromadzenia Księży Marianów w latach 19og1910, dokumenty, red. J. Bukowicz, T. Górski, tłum. H. Szymanel, Warszawa 1995, s. 60.

List o. W. Sękowskiego do ks. J. Matulewicza o trudnościach przywrócenia klasztoru w Mariampolu. Mariampol, 6 listopada 19o8, w: Odrodzenie Zgromadzenia Księży Marianów w latach 19og-1910, dokumenty, red. J. Bukowicz, T. Górski, tłum. H. Szymanel, Warszawa 1995, s. 59.

List o. W. Sękowskiego do ks. J. Matulewicza wyrażajacy radość z powodu zgłaszajacych się kandydatów do zakonu. Mariampol, 14 października 19o8, w: Odrodzenie Zgromadzenia Księży Marianów 
w latach 19og-1910, dokumenty, red. J. Bukowicz, T. Górski, tłum. H. Szymanel, Warszawa 1995, s. 56.

List o. W. Sękowskiego do ks. J. Matulewicza z zapytaniem, czy jest nadzieja na wznowienie klasztoru. Mariampol, 24 kwietnia 19og, w: Odrodzenie Zgromadzenia Księży Marianów w latach 1gog-1910, dokumenty, red. J. Bukowicz, T. Górski, tłum. H. Szymanel, Warszawa 1995, s. 61-62.

Pismo bpa podlaskiego Henryka Przeździeckiego do Kongregacji Zakonników, dotyczace ewentualnego przekazania mariańskiego klasztoru w Goźlinie Józefowi Pietrzakowi i jego towarzyszom. Siedlce, 10 grudnia 1927, w: Odrodzenie Zgromadzenia Księży Marianów w latach 19og-1910, dokumenty, red. J. Bukowicz, T. Górski, tłum. H. Szymanel, Warszawa 1995, s. 120-121.

Prośba generała W. Sękowskiego do Piusa X o zabezpieczenie istnienia marianów w sposób nadzwyczajny oraz upoważnienie ks. J. Matulewicza do załatwiania spraw zwiazanych z dalszym istnieniem zakonu. Mariampol, 20 lipca 19og, w: Odrodzenie Zgromadzenia Księży Marianów w latach 19og-1910, dokumenty, red. J. Bukowicz, T. Górski, tłum. H. Szymanel, Warszawa 1995, s. $67-69$.

Prośba generała W. Sękowskiego do Piusa X o zatwierdzenie nowych konstytucji. Mariampol, 7 sierpnia 1910, w: Odrodzenie Zgromadzenia Księży Marianów w latach 19og-1910, dokumenty, red. J. Bukowicz, T. Górski, tłum. H. Szymanel, Warszawa 1995, s. 106-107.

Prośba ks. Jerzego Matulewicza do generała Wincentego Sękowskiego o przyjęcie do zakonu jego wraz z przyjaciółmi. Petersburg, 8-g września 19o8, w: Odrodzenie Zgromadzenia Księży Marianów w latach 19og-1910, dokumenty, red. J. Bukowicz, T. Górski, tłum. H. Szymanel, Warszawa 1995, s. 51-52.

Protokół przyjęcia do Zgromadzenia Księży Marianów ks. J. Matulewicza $i$ ks. Fr. Buczysa przez wikariusza generalnego archidiecezji warszawskiej bpa Kazimierza Ruszkiewicza. Warszawa, 29 sierpnia 19og, w: Odrodzenie Zgromadzenia Księży Marianów w latach 19og1910, dokumenty, red. J. Bukowicz, T. Górski, tłum. H. Szymanel, Warszawa 1995, s. 86-87.

Reskrypt Kongregacji Zakonników do bpa podlaskiego H. Przeździeckiego wyjaśniajacy reformę Zgromadzenia Księży Marianów z roku 1910. Rzym, 25 kwietnia 1928, w: Odrodzenie Zgromadzenia Księży 
Marianów w latach 19og-1910, dokumenty, red. J. Bukowicz, T. Górski, tłum. H. Szymanel, Warszawa 1995, s. 122-124.

S. Papczyński, Ofiarowanie siebie. Oblatio, w: S. Papczyński, Pisma zebrane, red. A. Pakuła, tłum. K. Krzyżanowski, B. Kupis, W. Makoś, R.R. Piętka, R. Sawa, A. Stefańczyk, Warszawa 2007, s. 1422-1423.

Sprawozdanie ks. J. Matulewicza z życia wspólnoty mariańskiej w Petersburgu dla generała W. Sękowskiego. Petersburg, 3 października 19og, w: Odrodzenie Zgromadzenia Księży Marianów w latach 19og-1910, dokumenty, red. J. Bukowicz, T. Górski, tłum. H. Szymanel, Warszawa 1995, s. 87-90.

Wstepny reskrypt Kongregacji Zakonników dotyczacy odnowienia Zgromadzenia Księży Marianów. Rzym, 2 sierpnia 19og, w: Odrodzenie Zgromadzenia Księży Marianów w latach 19og-1910, dokumenty, red. J. Bukowicz, T. Górski, tłum. H. Szymanel, Warszawa 1995, s. 77-78.

\section{Opracowania}

Gach P., Zakon marianów w XIX wieku, w: Marianie 1673-1973, red. J. Bukowicz, T. Górski, Rzym 1975, s. 70-94.

Jakimowicz B., Stabilizacja i rozwój zakonu w XVIII wieku, w: Marianie 1673-1973, red. J. Bukowicz, T. Górski, Rzym 1975, s. 39-49.

Kałowski J., Ocena zarzutów przeciwko legalności odnowy Zakonu Marianów "Prawo Kanoniczne. Kwartalnik prawno-historyczny”, t. 21, Nr 3-4 (1978), s. 71-95.

Krzyżanowski K., Powstanie i rozwój zakonu za życia założyciela, w: Marianie 1673-1973, red. J. Bukowicz, T. Górski, Rzym 1975, s. 17-38.

Marecki J., Stowarzyszenie stanisławitów (1928-1955), „Folia Historica Cracoviensia", t. 9 (2003), s. 105-133.

Matulis S., Górski T., Odnowienie marianów, w: Marianie 1673-1973, red. J. Bukowicz, T. Górski, Rzym 1975, s. 97-118.

Matulis S., Marianie za błogosławionego Jerzego Matulaitisa-Matulewicza, Warszawa-Lublin 2008.

Olszewski D., Kontekst historyczno-religijny odnowienia Zakonu Marianów (XIX/XX w.), w: Za Chrystusa i Kościół. Materiały z sympozjum historyczno-teologicznego z okazji 10o. rocznicy odnowienia i reformy Zgromadzenia Księży Marianów (19og-20og), Licheń Stary, 24-28 maja 2009 r., red. J. Kumala, Licheń Stary 2010, s. 17-30. 


\section{Abstrakt}

Dmitrijs Artjomovs

Reforma Zakonu Księży Marianów w 1909 roku jako przykład "bezkonfliktowej" reformy

Zgromadzenie Księży Marianów Niepokalanego Poczęcia NMP na początku XX wieku okazało się na granicy wymarcia: w Mariampolu (Litwa) pozostał ostatni członek zgromadzenia o. Wincenty Sękowski. Ks. Jerzy Matulewicz zdecydował się na odnowienie zgromadzenia, jednak z powodu represji ze strony władz carskich nie dało się tego zrobić jawnie. Z tego powodu zaszła konieczność radykalnej reformy zgromadzenia.

Autor referatu na podstawie publikowanych dokumentów oraz opracowań prezentuje przebieg zmian oraz podejmuje próbę odpowiedzi na pytanie, dlaczego reforma przeszła bez konfliktów.

Pierwszą przyczyną braku konfliktu była niewielka grupa osób zaangażowanych w reformę, następnie - dobre rozumienie konieczności tych zmian przez wszystkich zainteresowanych. Kolejna przyczyna to współpraca zaangażowanych w reformę na zasadzie wzajemnego szacunku i zrozumienia. Na końcu należy zaznaczyć obecność i zaangażowanie w reformę władzy nadrzędnej - Stolicy Apostolskiej.

Ponadto, zaprezentowana jest i „druga strona medalu": działanie tzw. stanisławitów, czyli kapłanów nieuznających reformy, natomiast uważających się za "właściwych" marianów. Oni to, a także kilku późniejszych autorów, stanowią przykład opóźnionego oporu wobec już dokonanej reformy zgromadzenia. Konflikt ten jednak został już rozstrzygnięty przez kompetentną władzę kościelną.

Słowa kluczowe: Matulewicz, reforma, Sękowski, stanisławici, Zgromadzenie Marianów 


\title{
Abstract
}

\author{
Dmitrijs Artjomovs \\ Reform of the Congregations of the Marian Fathers in $190 \mathrm{~g}$ as an Example of a \\ "Non-conflict" Reform
}

Keywords:

association of

"stanisławici",

Congregation of Marian Fathers, Matulewicz, reform, Sękowski
The Congregation of Marian Fathers of the Immaculate Conception of the Most Blessed Virgin Mary in the beginning of the $20^{\text {th }}$ century was on the verge of the extinction: in the Mariampole (Lithuania) stayed only one member of the Congregation - Fr. W. Sekowski. Fr. J. Matulewicz decided to renew the Congregation, however it was impossible to do this manifestly, because of the repression from the side of the tsarist power. Thus, there was a necessity of the radical reform of the Congregation.

The author of this paper, basing on the published documents and descriptions, presents the course of changes and attempts to answer a question why these changes happened without conflicts.

The first reason for a lack of conflict is a small group of people involved in the reform, then - no bigger problem with proper understanding of the necessity of these changes by all interested. The next reason is cooperation full of respect and agreement between the people involved in the reform. Finally, it is important to mention presence and involvement of the overriding power - Holy See - in the reform.

Furthermore, the author presents "the other side of the coin": working of so called "stanisławici", or priests, who believed that there was not any reform and exactly they are proper Marian fathers. They and also some later authors are the example of the delayed resistance towards already finished reform of the Congregation. This conflict was resolved by the competent authority of the Church. 